\title{
Awareness of link between smoking and periodontal disease in Nigeria: a comparative study
}

This article was published in the following Dove Press journal:

Research and Reports in Tropical Medicine

30 September 2010

Number of times this article has been viewed

\author{
Solomon O Nwhator' \\ Patricia O Ayanbadejo 2 \\ Modupe O Arowojolu ${ }^{3}$ \\ Osagie Akhionbare ${ }^{4}$ \\ Adeleke O Oginni ${ }^{5}$ \\ 'Department of Preventive and \\ Community Dentistry, Obafemi \\ Awolowo University, Ile-Ife; \\ ${ }^{2}$ Department of Preventive Dentistry, \\ University of Lagos, ${ }^{3}$ Dental School \\ University College Hospital Ibadan, \\ ${ }^{4}$ Department of Periodontics, School \\ of Dentistry, College of Medical \\ Sciences, University of Benin, \\ Benin City; ${ }^{5}$ Department of \\ Restorative Dentistry, Obafemi \\ Awolowo University, lle-Ife, \\ Nigeria
}

Correspondence: Solomon O Nwhator Department of Preventive and Community Dentistry, Obafemi Awolowo University, Ile-Ife, Nigeria Tel +447943250080

Email nwhator32@yahoo.com
Objectives: To investigate Nigerians' awareness of the link between smoking and periodontal disease, and to compare our study findings with those of a similar UK study.

Design: The subjects, consisting of 992 adults, completed anonymous questionnaires. These subjects included patients and their escorts attending dental clinics located in four teaching hospitals in southwestern Nigeria. The teaching hospitals included the Lagos University Teaching Hospital, Obafemi Awolowo University Teaching Hospital, University College Hospital Ibadan, and the University of Benin Teaching Hospital.

Results: Smoking was considered dangerous to health by $96 \%$ of subjects, while $91 \%$ believed that it negatively impacted on oral health. Of those who believed smoking impacted negatively on oral health, $44 \%$ could not state how. Seventy percent of those who stated how smoking affects oral health associated smoking with dental stains and $12 \%$ associated it with halitosis, while $11 \%$ identified smoking as a causative agent of oral cancer. Only 20 subjects specifically stated that smoking affected the gums. This figure represents $2.2 \%$ of the total number of subjects, $2.4 \%$ of subjects who believed that smoking negatively impacted oral health, and $4.4 \%$ of subjects who could state a specific association between smoking and oral health. Male gender, nonsmoking status, and higher educational level were significantly associated with the level of awareness of negative effects of smoking on oral health. Ethnicity, number of previous dental visits, and reason for quitting had no impact on level of awareness.

Conclusions: This study found that the level of awareness of a link between smoking and periodontal disease is extremely low among Nigerians $(2.2 \%)$. The findings closely resemble those of the UK study although, expectedly, the level of awareness is much higher in the UK.

Keywords: smoking, awareness, periodontal diseases, Nigeria, United Kingdom

\section{Background}

The introduction to the UK study ${ }^{1}$ replicated by the current research cited a comment in a World Health Organisation report that "diseases such as periodontitis are a global health issue in both industrialized and developing countries", making such a study imperative in Nigeria, which enjoys a close relationship with the UK. It is against this backdrop that the authors decided to replicate the UK study, with a few modifications aimed at achieving two basic objectives, ie, to provide baseline data for Nigeria and to compare the findings in Nigeria with those obtained in the UK.

The level of awareness of a link between smoking and periodontitis in the UK, a country with a very long history of good dental care, was found to be low. This is both challenging and disturbing because, unlike the English, most Nigerians never visit the dentist except for the relief of toothache. Although the findings of the current study 
appear to be at variance with this assertion, the results must be interpreted cautiously because they are not fully representative of the Nigerian situation. Because the study was conducted in tertiary centers within academic institutions, most of the subjects belonged to a select group, ie, including people more aware of and more likely to be able to afford dental services. Therefore, by implication, the real situation in Nigeria will be worse than the already appalling picture painted here. On a positive note though, the prevalence and extent of smoking in Nigeria is currently much lower than that of highly industrialized and more affluent nations. ${ }^{2-4}$

Emerging facts from the relatively new field of periodontal medicine ${ }^{5-7}$ show that, unlike in the past when dentists were concerned about the oral manifestations of systemic diseases, there has been a gradual but definite paradigm shift. Emphasis is shifting from the traditional one-way view to the more robust view of the influence of periodontitis on general health. Again, unlike many of the risk factors for periodontitis, including genetic predisposition, male gender, and diabetes mellitus, ${ }^{8}$ smoking is a controllable independent risk factor for chronic periodontitis. ${ }^{9}$

Many mechanisms for smoking-associated periodontitis have been reported in the literature. These include increased calculus formation, ${ }^{10}$ greater gingival inflammation ${ }^{11,12}$ masked by reduced gingival bleeding due to the vasoconstrictive effects of nicotine, ${ }^{13,14}$ and lower hemorrhagic responsiveness in smokers. ${ }^{15}$ Other mechanisms include decreased calcium deposition in the alveolar bone in smokers, ${ }^{16}$ increased subgingival temperature, ${ }^{17}$ reduced pocket oxygen tension, ${ }^{18}$ and a consequent selective favoring of periodontopathic Gram-negative anerobes. ${ }^{19}$ When a pocket is eventually formed, impaired neutrophil function ${ }^{20,21}$ and nicotinealtered fibroblasts ${ }^{22}$ ensure increased attachment loss. ${ }^{23}$ All these factors contribute to and culminate in the increased prevalence of refractory periodontitis among smokers.

Unfortunately, the Nigerian warning slogan "smokers are liable to die young" has failed to discourage the smoking habit. However, the disappearance of overt/direct tobacco billboards in Nigeria is a welcome development, although the lack of awareness of the link between smoking and periodontal disease is alarming and demands urgent attention.

\section{Methods}

We carried out a prospective, cross-sectional survey over a period of months utilizing convenience sampling by means of anonymous questionnaires (Table 1). These anonymous questionnaires were completed by subjects who were patients and escorts visiting the dental hospitals within four tertiary health centers in southwestern Nigeria. Information requested in the questionnaires included age, occupation, educational level, gender, ethnic origin, smoking status, duration, degree, and reason for quitting where applicable.

A total of 902 subjects were included, comprising 418 males and 484 females, of whom 26 (2.9\%) were smokers and $10(1.1 \%)$ were former smokers. The mean age of the subjects was $31 \pm 12.7$ years. Their ethnic distribution was Yoruba (66.3\%), Igbo (10.3\%), and Bini (6.7\%), while other tribes comprised $16.7 \%$. Records of the highest educational level attained showed that 10 subjects $(1.1 \%)$ had no formal education, $25(2.8 \%)$ had only primary education, $144(16 \%)$ had attained secondary education, $723(80.2 \%)$ were either undergraduates or had tertiary education, and some $(0.4 \%)$ had reached $\mathrm{PhD}$ level. Eighty percent of the former smokers had quit for medical reasons, while $20 \%$ had quit out of sheer determination alone (Table 2).

\section{Statistical analysis}

SPSS statistical software (version 11.0; SPSS Inc, Chicago, IL) was used for data entry and analysis. The association of each categoric variable with awareness was assessed using univariate analysis. The Chi-square statistic was used for the comparison of association of the various categoric variables with awareness. The Student's $t$-test, Fisher's exact test, and other descriptive statistics were utilized when and as appropriate. Statistical tests yielding $P$ values $\leq 0.05$ were considered significant.

\section{Results}

\section{Patient awareness of link between smoking and periodontal disease}

Ninety-one percent $(n=821)$ of the respondents believed that smoking impacted negatively on oral health (Table 3 ). Statistical analyses show that male gender, nonsmoking status, and higher educational level were significantly associated with the level of awareness of the negative effects of smoking on oral health $(P=0.03$ for each of the three variables). Ethnicity, number of previous dental visits, and reason for quitting smoking had no impact on the level of awareness. The highest level of awareness was among the Yoruba ethnic group, but this did not attain statistical significance.

\section{Manner in which tobacco is believed to affect oral health}

Ninety-six percent of subjects considered smoking to be dangerous to health, while $91 \%$ believed that smoking 
Table I Questionnaire administered to subjects in this study

In order to understand and meet the dental needs of the community could you please complete this questionnaire? Please tick the box that best describes your answer and provide further information where asked. Thank you for your help.

I) a. What is your age?...............years b. Occupation........... c. Highest educational level attained......

2) What is your gender? Female Male

3) To which of the following groups do you belong?

- Yoruba

- Hausa

- Efik

- Ebira

- Ibibio

- Itsekiri

- Fulani

- Tir

- Igbo

- Jiaw

- Egun

- Other African tribe

- Indian

- European

- Other (please specify)

4) When last did you visit a dentist? 0-6 months 7-12 months Over one year Never

5) Reason for dental attendance or nonattendance

6) Do you smoke? Yes No

7) If you smoke, do you smoke cigarettes cigars pipe marijuana?

8) If you smoke, how much do you smoke a day? Less than five 5-10 More than 10

9) How many years have you smoked? Less than five years More than five years

10) Do you use tobacco in any other way? Yes No

II) If yes, in what form do you take tobacco (chew tobacco, take snuff, etc)

Even if you do not smoke or use tobacco please answer the questions below:

12) Do you know that smoking is not good for you? Yes No

13) Are you aware that tobacco can affect your oral and dental health? Yes No

14) If yes, how do you think smoking or using tobacco affects the inside of your mouth?

15) If you have smoked in the past, how many years have you been a nonsmoker? Years

16) Why did you stop smoking? (Please tick the box that strongly applies to you)

Medical reasons Dental health reasons

Expensive habit Other - please specify.

Peer pressure Increasing number of nonsmoking areas

negatively impacted oral health, of whom $44 \%$ could not specifically state how it affects health (Table 4). Seventy percent of those who stated how smoking affects oral health believed it causes dental stains, $12 \%$ associated it with halitosis, while $11 \%$ identified smoking as a causative agent for oral cancer. Only 20 subjects specifically stated that smoking affects the gums. This number represents $2.2 \%$ of the total number of subjects.

\section{Discussion}

This study was intended to replicate a UK study because of the long and close sociopolitical history between the two countries. Smoking is not considered as serious a menace as it is in the UK and most other Western countries. While the efforts of antitobacco coalitions are beginning to yield fruits in the Western world, the tobacco multinational companies have been targeting developing countries. Therefore, it is imperative for health professionals to start making concerted efforts at creating awareness before many more people, especially youth, adopt the habit.

Like the UK study, nonsmoking status was one of the determinants of awareness. However, unlike the UK study, registration with a GDP was not even considered because it is not a common practice in Nigeria; as previously stated, most Nigerians only visit dentists for the relief of toothache. ${ }^{24}$

The significant association between educational level and awareness is consistent with the findings of previous studies. ${ }^{25,26}$ Nonsmokers in both the Nigerian and the UK study were more aware of the negative oral effects of smoking, indicating that nonsmokers are probably more health conscious. This finding corroborates the suggestion 
Table 2 Frequency distribution of patient characteristics (for all respondents and by beliefs)

\begin{tabular}{|c|c|c|c|c|c|c|c|c|}
\hline & \multicolumn{2}{|c|}{ Overall sample } & \multicolumn{2}{|c|}{$\begin{array}{l}\text { Believe smoking } \\
\text { is bad }\end{array}$} & \multicolumn{2}{|c|}{$\begin{array}{l}\text { Do not believe } \\
\text { smoking is bad }\end{array}$} & \multicolumn{2}{|c|}{ Do not know } \\
\hline & $n=902$ & $\%$ & $n=869$ & $96.3 \%$ & $n=28$ & $3.1 \%$ & $n=5$ & $0.6 \%$ \\
\hline \multicolumn{9}{|l|}{ Gender } \\
\hline Male & 418 & $46.3 \%$ & 408 & $47.0 \%$ & 9 & $32.1 \%$ & I & $20.0 \%$ \\
\hline Female & 484 & $53.7 \%$ & 461 & $53.0 \%$ & 19 & $67.9 \%$ & 4 & $80.0 \%$ \\
\hline Total & 902 & $100 \%$ & 869 & $100 \%$ & 28 & $100 \%$ & 5 & $100 \%$ \\
\hline \multicolumn{9}{|l|}{ Dental visits } \\
\hline Visited & 601 & $66.6 \%$ & 580 & $66.7 \%$ & 18 & $64.3 \%$ & 3 & $60.0 \%$ \\
\hline Not visited & 301 & $33.4 \%$ & 289 & $33.3 \%$ & 10 & $35.7 \%$ & 2 & $40.0 \%$ \\
\hline Total & 902 & $100 \%$ & 869 & $100 \%$ & 28 & $100 \%$ & 5 & 100 \\
\hline \multicolumn{9}{|l|}{ Education } \\
\hline None & 10 & $1.1 \%$ & 9 & $1.0 \%$ & 1 & $3.6 \%$ & 0 & 0 \\
\hline Primary & 25 & $2.8 \%$ & 23 & $2.6 \%$ & 2 & $7.1 \%$ & 0 & 0 \\
\hline Secondary & 144 & $16.0 \%$ & 136 & $15.7 \%$ & 7 & $25.0 \%$ & 1 & $20.0 \%$ \\
\hline Undergraduate & 340 & $37.7 \%$ & 328 & $37.7 \%$ & 10 & $35.7 \%$ & 2 & $40.0 \%$ \\
\hline Tertiary & 379 & $42.0 \%$ & 369 & $42.5 \%$ & 8 & $28.6 \%$ & 2 & $40.0 \%$ \\
\hline $\mathrm{PhD}$ & 4 & $0.4 \%$ & 4 & $0.5 \%$ & 2 & 0 & 0 & 0 \\
\hline Total & 902 & $100 \%$ & 869 & $100 \%$ & 8 & $100 \%$ & 5 & $100 \%$ \\
\hline \multicolumn{9}{|l|}{ Smoke } \\
\hline Yes & 26 & $2.9 \%$ & 24 & $2.8 \%$ & 2 & $7.1 \%$ & 0 & 0 \\
\hline No & 876 & $97.1 \%$ & 845 & $97.2 \%$ & 26 & $92.9 \%$ & 5 & $100 \%$ \\
\hline Total & 902 & $100 \%$ & 869 & $100 \%$ & 28 & $100 \%$ & 5 & $100 \%$ \\
\hline \multicolumn{9}{|l|}{ Why stop } \\
\hline Medical & 8 & $80.0 \%$ & 8 & $80.0 \%$ & 0 & 0 & 0 & 0 \\
\hline Expensive & 0 & 0 & 0 & 0 & 0 & 0 & 0 & 0 \\
\hline Personal desire & 2 & $20.0 \%$ & 2 & $20 \%$ & 0 & 0 & 0 & 0 \\
\hline Total & 10 & $100 \%$ & 10 & $100 \%$ & 0 & 0 & 0 & 0 \\
\hline \multicolumn{9}{|l|}{ Ethnicity } \\
\hline Yoruba & 598 & $66.3 \%$ & 576 & $66.3 \%$ & 17 & $60.7 \%$ & 5 & $100 \%$ \\
\hline Igbo & 93 & $10.3 \%$ & 92 & $10.6 \%$ & I & $3.6 \%$ & 0 & 0 \\
\hline Bini & 60 & $6.7 \%$ & 55 & $6.3 \%$ & 5 & $17.9 \%$ & 0 & 0 \\
\hline Others & $|5|$ & $16.7 \%$ & 146 & $16.8 \%$ & 5 & $17.9 \%$ & 0 & 0 \\
\hline Total & 902 & $100 \%$ & 869 & $100 \%$ & 28 & $100 \%$ & 5 & $100 \%$ \\
\hline
\end{tabular}

of our English colleagues. It also raises the hope that disseminating more information on the negative oral impact of smoking might do more to nip the habit in the bud than the current "smokers are liable to die young" slogan which seems to have degenerated to mere rhetoric. Furthermore, as rightly observed by our English counterparts, the undue emphasis on oral cancer as a consequence of smoking has not achieved much in discouraging the habit. The fact that $12 \%$ of the English subjects and $4.5 \%$ of Nigerian subjects were aware of the link between smoking and oral cancer is quite informative. It is more disturbing to note that $34 \%$ of those aware of this link with cancer were health care professionals.

What is somewhat paradoxical about our observations is the association between awareness and gender. This is more so because smoking is not a popular habit among Nigerian females. In a cross-sectional survey involving 254 factory workers (184 male and 70 female) Nwhator ${ }^{27}$ identified 61 smokers, all of whom were males. Savage ${ }^{28}$ reported similar findings. A possible explanation for this is the fact that females in the current study were more educated than males, and $60 \%$ of those with at least secondary school education and $70 \%$ of those who possessed higher certificates were female. Could it be that females in the current study were more conscious of aesthetics and so were more reluctant to take up smoking? On the other hand, were they really more health conscious than their male counterparts? A closer look at the responses does not support either of these hypotheses because there was no significant gender predilection for stating stains to be a negative effect of smoking $(P=0.3)$, neither was there any significant association between stating halitosis as a negative effect and gender $(P=0.8)$. Therefore, it does 
Table 3 Univariate test on the association of different variables with patient awareness of link between smoking and periodontal disease

\begin{tabular}{|c|c|c|c|c|c|c|c|}
\hline & \multicolumn{2}{|c|}{ Overall sample } & \multicolumn{2}{|c|}{ Believe smoking is bad } & \multicolumn{2}{|c|}{$\begin{array}{l}\text { Do not believe smoking } \\
\text { is bad }\end{array}$} & \multirow[t]{2}{*}{$P$ value } \\
\hline & $\mathrm{n}=902$ & $\%$ & $\mathbf{n}=821$ & $91 \%$ & $n=81$ & $9.0 \%$ & \\
\hline \multicolumn{8}{|l|}{ Gender } \\
\hline Male & 418 & $46.3 \%$ & 371 & 45.2 & 47 & $58.0 \%$ & $\chi^{2}=4.89$ \\
\hline Female & 484 & $53.7 \%$ & 450 & 54.8 & 34 & $42.0 \%$ & $d f=I$ \\
\hline Total & 902 & $100 \%$ & 821 & $100 \%$ & 81 & $100 \%$ & $P=0.003$ \\
\hline \multicolumn{8}{|l|}{ Dental visits } \\
\hline Visited & 601 & $66.6 \%$ & 552 & $67.2 \%$ & 49 & $60.5 \%$ & $\chi^{2}=|.5|$ \\
\hline Not visited & 301 & $33.4 \%$ & 269 & $32.8 \%$ & 32 & $39.5 \%$ & $\mathrm{df}=\mathrm{I}$ \\
\hline Total & 902 & $100 \%$ & 821 & $100 \%$ & 81 & $100 \%$ & $P=0.22$ \\
\hline \multicolumn{8}{|l|}{ Education } \\
\hline Up to secondary only & 179 & $19.8 \%$ & 154 & $18.7 \%$ & 29 & $35.8 \%$ & $\chi^{2}=7.28$ \\
\hline Undergraduate & 340 & $37.7 \%$ & 311 & $37.9 \%$ & 25 & $30.9 \%$ & $\mathrm{df}=2$ \\
\hline Tertiary and $\mathrm{PhD}$ & 383 & $42.5 \%$ & 356 & $43.4 \%$ & 27 & $33.3 \%$ & $P=0.03$ \\
\hline Total & 902 & $100 \%$ & 821 & $100 \%$ & 81 & $100 \%$ & \\
\hline \multicolumn{8}{|l|}{ Smoke } \\
\hline Yes & 26 & $2.9 \%$ & 20 & $2.4 \%$ & 6 & $7.4 \%$ & $\begin{array}{l}\chi^{2}(\text { Yate's } \\
\text { corrected })=4.85\end{array}$ \\
\hline No & 876 & $97.1 \%$ & 801 & $97.6 \%$ & 75 & $92.6 \%$ & \\
\hline Total & 902 & $100 \%$ & 821 & $100 \%$ & 81 & $100 \%$ & $P=0.03$ \\
\hline \multicolumn{8}{|l|}{ Reason for stopping } \\
\hline Medical & 8 & $80.0 \%$ & 8 & $80.0 \%$ & 0 & 0 & Not applicable \\
\hline Expensive & 0 & 0 & 0 & 0 & 0 & 0 & \\
\hline Personal desire & 2 & $20.0 \%$ & 2 & $20.0 \%$ & 0 & 0 & \\
\hline Total & 10 & $100 \%$ & 10 & $100 \%$ & 0 & 0 & \\
\hline \multicolumn{8}{|l|}{ Ethnicity } \\
\hline Yoruba & 598 & $66.3 \%$ & 546 & $66.5 \%$ & 17 & $60.7 \%$ & $\chi^{2}=6.21$ \\
\hline Igbo & 93 & $10.3 \%$ & 85 & $10.4 \%$ & 1 & $3.5 \%$ & $\mathrm{df}=3$ \\
\hline Bini & 60 & $6.7 \%$ & 51 & $6.2 \%$ & 5 & $17.9 \%$ & $P=0.10$ \\
\hline Others & $|5|$ & $16.7 \%$ & 139 & $16.9 \%$ & 5 & $17.9 \%$ & \\
\hline Total & 902 & $100 \%$ & 821 & $100 \%$ & 28 & $100 \%$ & \\
\hline
\end{tabular}

appear that educational level had an overriding influence on gender, and that future efforts at increasing awareness should be mainly directed towards health education. It is noteworthy that all former smokers in our study were aware of the adverse oral effects of smoking. This corroborates the findings of the UK study. ${ }^{1}$

\section{Periodontitis and smoking}

Smoking has not only been recognized as an independent risk ${ }^{9}$ factor for periodontitis, but a direct dose-response relationship has also been established between them. ${ }^{29-31}$ Smoking predisposes to and aggravates existing periodontal disease through its effects on several determinants of periodontal health. The recognition of smoking as an independent risk factor for periodontitis stems from the fact that it exerts its influence in spite of known risk factors for periodontitis including age, gender, race, oral hygiene status, and socioeconomic class. ${ }^{9}$
This is more so because the periodontal effects of smoking, although manifested locally, are systemically mediated. This systemic mediation is via humoral, hematologic, vascular, microbiologic, and direct toxic effects on tissues. Smoking affects periodontal tissues to the level of DNA changes. ${ }^{32} \mathrm{At}$ the humoral level, smoking is known to cause up to $50 \%$ or more of neutrophil chemotaxis and phagocytosis. ${ }^{21,33}$ While smokers exhibit increased numbers of peripheral blood mononuclear phagocytes, these phagocytes are functionally defective, ${ }^{34}$ and the result could be reduced oral clearance of pathogens and increased attendant periodontitis. The much emphasized vasoconstrictive effects of nicotine on gingival tissues is a transient phenomenon. ${ }^{35}$ Gingival blood flow has actually been observed to increase during smoking. It was concluded in one study ${ }^{36}$ that vascular dysfunction and periodontal disease in smokers might be the result of repeated (transient) ischemic attacks. 
Table 4 How tobacco is believed to affect oral and dental health (for 821 subjects who were aware that smoking affects oral/ dental health)

\begin{tabular}{lll}
\hline & $\mathbf{n}$ & $\%$ \\
\hline Bleeding & $\mathrm{I}$ & 0.1 \\
Burns & $\mathrm{I}$ & 0.1 \\
Calculus & $\mathrm{I}$ & 0.1 \\
Cancer & 37 & 4.1 \\
Caries & 3 & 0.3 \\
Cell damage & 2 & 0.2 \\
Gum disease & 20 & 2.2 \\
Halitosis & 53 & 5.9 \\
III heath & $\mathrm{I}$ & 0.1 \\
Infection & 5 & 0.6 \\
Irritation & 2 & 0.2 \\
Keratosis & 2 & 0.2 \\
Pain & $\mathrm{I}$ & 0.1 \\
Plaque & $\mathrm{I}$ & 0.1 \\
Poison & $\mathrm{I}$ & 0.1 \\
Stains & 323 & 35.8 \\
Ulcer & 2 & 0.2 \\
Do not know & 365 & 44.5 \\
Total & $82 \mathrm{I}$ & 100.0 \\
\hline
\end{tabular}

Furthermore, smokers experience reduced pocket oxygen tension and a selective favoring of anerobic Gram-negative organisms. ${ }^{19,20}$ The resulting aggravated chronic periodontitis is mediated via defective immune responses, ${ }^{21,33}$ nicotine-altered fibroblasts, ${ }^{22}$ and direct DNA damage through the production of promutagenic 1, $\mathrm{N}_{2}$-propanodeoxyguanosine adducts and sICAM-.$^{32,36}$ All these events progress unnoticed because of reduced gingival bleeding in smokers. However, the reduced gingival bleeding experienced by smokers is only a mask, because Katsuragi et $\mathrm{al}^{37}$ found greater levels of metallothionein (a tissue marker of gingival inflammation) in smokers.

\section{Smoking cessation advice}

It has been shown that oral health problems could be a major motivation for subjects to quit smoking. ${ }^{38}$ Smoking cessation counseling is very rarely offered by Nigerian dentists, who might only be disposed to suggest that subjects quit if they have heavy stains.

Knowledge of the various options for smoking cessation $^{39,40}$ is very low in Nigeria, probably because smoking is not yet recognized to be as serious an issue as it is in more developed countries. The authors share the sentiments expressed in a recent Nigerian study, that the low prevalence of smoking in Nigeria stems from Nigerians already having enough economic problems without wasting their scarce resources on smoking and from the hot weather (as in the Western world) which does not encourage the smoking habit. Opportunities for training in smoking cessation are also scarce in Nigeria, making this skill a rarity among Nigerian dentists. It is hoped that improved awareness of the need for such counseling and availability of training facilities in this regard will improve the current situation.

The developed world should see the provision of training for Nigerian and other African health care professionals as a service to humanity to save Africa's poor populations from the influx of tobacco companies under the guise of providing employment. While the civilized world is battling to cope with the adverse effects of smoking on general and oral health, the current trend of embracing these multinational tobacco companies in Africa should be openly condemned. Considering the level of poverty in Africa though, this will take more than mere lip service to achieve.

\section{Conclusion}

The current level of awareness of the link between smoking and periodontal disease among Nigerians is $2.2 \%$. This is abysmally low. The currently unacceptable level of awareness of the link between smoking and periodontitis in Nigeria, as well as in the UK, shows that this is a global problem which transcends the divides of gender, culture, civilization, and educational and socioeconomic status.

\section{Disclosure}

The authors report no conflicts of interest in this work.

\section{References}

1. Lung ZH, Kelleher MG, Porter RW, Gonzalez J, Lung RF. Poor patient awareness of the relationship between smoking and periodontal diseases. Br Dent J. 2005;199(11):731-737.

2. Abdulkarim AA, Mokuolu OA, Adeniyi A. Drug use among adolescents in Ilorin, Nigeria. Trop Doct. 2005;35(4):225-228.

3. Alagh TB, Omokhodion FO. Health related practices of students of the University of Ibadan. Afr J Med Med Sci. 2004;33(2):109-114.

4. Ibeh CC, Ele PU. Prevalence of cigarette smoking in young Nigerian females. Afr J Med Med Sci. 2003;32(4):335-338.

5. Mattila KJ. Dental infections as a risk factor for acute myocardial infarction. Eur Heart J. 1993;14 Suppl K:51-53.

6. Mealey BL. Influence of periodontal infections on systemic health. Periodontol 2000. 1999;21:197-209.

7. Mealey BL. Diabetes mellitus. In: Rose LF, Genco RJ, Mealey BL, et al, editors. Periodontal Medicine. Toronto, Canada: Decker; 2000.

8. Locker D, Leake JL. Risk factors and risk markers for periodontal disease experience in older adults living independently in Ontario Canada. J Dent Res. 1993;72(1):9-17.

9. Salvi GE, Lawrence HP, Offenbacher S, Beck JD. Influence of risk factors on the pathogenesis of periodontitis. Periodontol 2000. 1997;14: 173-201.

10. Ainamo J. The seeming effect of tobacco consumption on the occurrence of periodontal disease and caries. Suom Hammaslaak Toim. 1971;67: 87-94.

11. Arno A, Schei O, Lovdal A, Waerhug J. Alveolar bone loss as a function of tobacco consumption. Acta Odontol Scand. 1959;17:3-10. 
12. Frandsen AM, Pindborg JJ. Tobacco and gingivitis; difference in the action of cigarette and pipe smoking. $J$ Dent Res. 1949;28(5):404-408.

13. Bergström J, Floderus-Myrhed B. Co-twin control study of the relationship between smoking and some periodontal disease factors. Community Dent Oral Epidemiol. 1983;11(2):113-116.

14. Palmer RM. Tobacco smoking and oral health. Br Dent J. 1988;164(8): 258-260.

15. Bergstorm J, Bostrom L. Tobacco smoking and periodontal haemorrhagic responsiveness. J Clin Periodontol. 2001;28(7):680-685.

16. Krail LA, Dawson-Hughes B. Smoking and bone loss among postmenopausal women. J Bone Miner Res. 1991;6(4):331-338.

17. Dinsdale CR, Raulinson A, Walsh TF. Subgingival temperature in smokers and non-smokers with periodontal disease. J Clin Periodontol. 1997;24(10):761-766.

18. Hanioka T, Tanaka M, Takaya K, Matsumori Y, Shizukuishi S. Pocket oxygen tension in smokers and non-smokers with periodontal disease. J Periodontol. 2000;71(4):550-554.

19. van Winkelhoff AJ, Bosch-Tijhof CJ, Winkel EG, van der Reijden WA. Smoking affects the subgingival microflora in periodontitis. J Periodontol. 2001;72(5):666-671.

20. Armitage AK, Dolley CT, George CF, et al. Absorption and metabolism of nicotine from cigarette. $\mathrm{Br}$ Med J. 1975;4(5992):313-318.

21. Bridges RB, Krail JH, Hwang LJT, Chancellor MB. The effects of tobacco smoke on chemotaxis and glucose metabolism of polymorphonuclear leukocytes. Infect Immun. 1977;15(1):115-123.

22. Raulin CA, McPherson JC, McQuade MJ, Hanson BS. The effect of nicotine on the attachment of human fibroblast to glass and human root surface in vitro. $J$ Periodontol. 1988;59(5):318-325.

23. Ashril NY, Al-Sulamani A. The effect of different types of smoking habits on periodontal attachment. J Int Acad Periodontol. 2003;5(2): 41-46.

24. Ayanbadejo PO. Periodontal awareness and periodontal status of diabetics in the Lagos metropolis. Dissertation submitted to the National Postgraduate Medical College of Nigeria. 1995.

25. Reddy P, Meyer-Weitz A, Yach D. Smoking status, knowledge of health effects and attitudes towards tobacco control in South Africa. S Afr Med J. 1996;86(11):1389-1393.

26. Jarvis MJ, Wardle J, Marmot M, Wilkinson RG. Social patterning of individual health behaviours: The case of cigarette smoking. In: Social Determinants of Health. Oxford, UK: Oxford University Press; 1999.
27. Nwhator SO. Periodontal disease in smokers: A study of factory workers in Lagos state. A dissertation submitted to the National Postgraduate Medical College of Nigeria. May, 2005.

28. Savage KO. Assessment of periodontal status of Nigerian factory workers in relation to cigarette smoking in Lagos. Nig $Q J$ Hosp Med. 1999;9(3):198-201.

29. Calsina G, Ralmon JM, Echeverria JJ. Effects of smoking on periodontal tissues. J Clin Periodontol. 2002;29(8):771-776.

30. Schwartz-Arad D, Samet N, Samet N, Mamlider A. Smoking and complications of endosseous dental implants. J Periodontol. 2002; 73(2):153-157.

31. Taani DS. Association between cigarette smoking and periodontal health. Quintessence Int. 1997;28(8):535-539.

32. Nath RG, Ocando JE, Guttenplan JB, Chung FL. 1, $\mathrm{N}_{2}$-propanodeoxyguanosine adducts: Potential new biomarkers of smoking-induced DNA damage in human oral tissue. Cancer Res. 1998;58(4):581-584.

33. Persson L, Bergstrom J, Gustafson A, Asman B. Tobacco smoking and gingival neutrophil activity in young adults. J Clin Periodontol. 1999; 26(1):9-13.

34. Barbour SE, Nakashima K, Zhang JB, et al. Tobacco and smoking: Environmental factors that modify the host response (immune system) and have an impact on periodontal health. Crit Rev Oral Biol Med. 1997; 8(4):437-460

35. Mavropoulos A, Aars H, Brodin P. Hyperaemic response to cigarette smoking in healthy gingiva. J Clin Periodontol. 2003;30(3):214-221.

36. Palmer RM, Scott DA, Meekin TN, Poston RN, Odell EW, Wilson RF Potential mechanisms of susceptibility to periodontitis in tobacco smokers. J Periodont Res. 1999;34(7):363-369.

37. Katsuragi H, Hasegawa A, Saito K. Distribution of metallothionein in cigarette smokers and non-smokers in advanced periodontitis subjects. J Periodontol. 1997;68(10):1005-1009.

38. John JH, Thomas D, Richards D. Smoking cessation intervention in the Oxford region: Changes in dentists' attitudes and reported practices 1996-2001. Br Dent J. 2003;195(5):270-275.

39. Lichtenstein E, Wallack L, Pechacek TF; COMMIT Research Group (1990/91). Introduction to the Community Intervention Trial for Smoking Cessation (COMMIT). Int Q Community Health Educ. 11: 271-290.

40. Imperial Cancer Research Fund General Practice Study Group. Randomized trial of nicotine patches in general practice: Results at one year. Br Dent J. 1993;308:1476-1477.
Research and Reports in Tropical Medicine

\section{Publish your work in this journal}

Research and Reports in Tropical Medicine is an international, peerreviewed, open access journal publishing original research, case reports, editorials, reviews and commentaries on all areas of tropical medicine, including: Diseases and medicine in tropical regions; Entomology; Epidemiology; Health economics issues; Infectious disease; Laboratory

\section{Dovepress}

science and new technology in tropical medicine; Parasitology; Public health medicine/health care policy in tropical regions; and Microbiology. The manuscript management system is completely online and includes a very quick and fair peer-review system. Visit http://www.dovepress. com/testimonials.php to read real quotes from published authors. 